\title{
Gram Positive Coccus
}

National Cancer Institute

\section{Source}

National Cancer Institute. Gram Positive Coccus. NCI Thesaurus. Code C86424.

Any spherical shaped bacteria that has a peptidoglycan rich cell wall that stains dark purple with the Gram staining technique. 